\title{
Transformational Leadership Behaviors of High School Students' According to Leisure Preferences and Participation Type
}

\author{
Umit Dogan Ustun ${ }^{1, *}$ \\ ${ }^{1}$ School of Physical Education and Sports Mustafa Kemal University, Hatay, Turkey \\ *Correspondence: School of Physical Education and Sports Mustafa Kemal University, Hatay, Turkey, Tel: \\ 90-546-898-5064. E-mail: umit.dogan.ustun@gmail.com
}

Received: June 26, 2018

Accepted: July 11, 2018 Online Published: July 23, 2018

doi:10.5430/wje.v8n4p18

URL: https://doi.org/10.5430/wje.v8n4p18

\begin{abstract}
This paper aimed to investigate the transformational leadership behavior of high school students according to leisure preferences and participation type. 226 high school students attending Bursa Atatürk High School participated in the study voluntarily. In the study, to collect data transformational and transactional leadership scale developed by Başoğlu (2013a) was revised and used. The construct validity of the scale assessed by confirmatory \& explanatory factor analyzes. To investigate the differences between the participants' transformational leadership behavior Kruskal Wallis and Mann Whitney U nonparametric tests used. As a result, this study showed that students who chose physical activities and who actively involved in leisure activities showed more transformational leadership than the other students.
\end{abstract}

Keywords: transformational leadership, leisure preference, high school students

\section{Introduction}

When we examine the literature related to leadership, we can see that although researchers have reached a consensus on the definition of the leader, they could not reach a consensus on the concept of leadership. As a result of this conflict, the concept of leadership investigated in different forms. The first one of these forms sees leadership as a "status" or "position." The second one sees a "personality," and the third one sees leadership as "behavior" (Akoğlan Kozak, 2017, p.62). If we take the third form mentioned above, we can define the leadership as the behaviors which the leader influences and directs the attitudes of others to achieve personal or group goals. Therefore, leadership behaviors requires a great deal of responsibilities such as, establishing an interaction structure for the solution of a common problem, establishing the relations between the leader and the group members, determining the communication channels, establishing the group goals by creating respect, trust, sincerity and friendship within the group (Serinkan, 2008).

Previous research done on leadership shows that there were a variety of approaches aimed at explaining leadership (Bass, 1985, 1990; Bass \& Stogdill, 1989; Bryman, 1992; Gardner, 1990) but among these leadership theories existing in the literature, one of the most investigated leadership theory of the last twenty years is thought to be transformational leadership (Avolio \& Yammarino, 2013).

\subsection{Transformational Leadership}

It is possible to divide leadership theories into two categories: classical and postmodern approaches. Transformational leadership belongs the latter and although, initially developed to discuss certain politicians' governing style (Burns, 1978), the concept of the theory expanded by the frontier works of Bass and his associates (Bass, 1985; Bass \& Avolio, 1993).

Transformational leadership is a type of leadership in which the behavior of the leader is observable and measurable (Andrea, 2011). Transformational leadership represents a sense of leadership-oriented towards the future, innovation, change and reformation (Sabuncuoğlu, 2008). Transformational leaders are leaders who seek new ways to work, generate new opportunities against risks, produce practical solutions to problems and reject status quo (Lowe, Kroeck, \& Sivasubramaniam, 1996). According to Bass (1999), transformational leaders followed by their charisma, inspiration, and intellectuality. It elevates the follower's level of maturity and ideas as well as concerns for 
achievement.

\subsection{Leisure and Leadership}

According to Karaküçük (2005), general leadership and leisure leadership, which are essential in management, are close to each other regarding the functions expected from the leaders (p.257). Good leadership in leisure management requires an understanding of the goals of the organization, its services, facilities, programs, and resources. It also requires knowledge of the people involved: ourselves, colleagues, clients, and customers (Torkildsen, 2005, p.418).

We need leadership at all levels of leisure services because leisure services help women and men of all ages, regardless of income levels and disabilities (Jordan 2007: 3). Individuals take part in leisure activities to increase their quality of life (Schmiedeberg \&Schröder, 2017), to socialize (Asakitikpi, Adeyemi \& Nnamani, 2018), or to have fun and enjoy (Kanagasabai, Mulligan, Hale \& Mirfin-Veitch). To experience all the positive effects of leisure activities and services good leadership gains importance because a poor leisure experience may leave a participant with negative feelings and a desire to avoid other similar leisure opportunities (Jordan 2007: 3).

\subsection{Present Study}

Reviewing literature related to leadership and leisure it can be seen that the majority of the research focused on two topics: 1) transactional 2) transformational (Bass, 1990; Fields \& Herold, 1997). In the present study, we focused on high school students transformational leadership behaviors according to their leisure preferences and participation type because active or passive participation in different kind of leisure activities needs different leadership behaviors. Besides, in the existing literature although there are studies which investigate the positive aspects of transformational leadership behaviors of high school students on different topics (e.g., Leithwood \& Jantzi, 2000; Sun \& Leithwood, 2012), there are only a few studies conducted on the connection of students' transformational leadership behaviors and leisure. So this paper can contribute to further studies.

\section{Method}

\subsection{Study Sample and Sampling Procedures}

226 high school students from Bursa Atatürk High School who selected by random sampling method participated in the study. Data gathered in the 2013-2014 academic year. According to the random sampling method, each subject forming the universe is likely to be equally involved in the sample (Ural \& Kılıç, 2011, p.38),

\subsection{Data Collection Tool}

In the study to collect data after making some modifications the Transformational and Transactional Leadership Scale which was developed by Başoğlu (2013a) used. The scale is a self-report scale with eight items emphasizing specific leader behaviors such as challenging the process, inspiring and enabling others to act, and anchored with five Likert type scale from 1 (strongly disagree) to 5 (strongly agree).

\subsection{Data Collection Procedure}

The data was obtained using the face-to-face interview method at the beginnings of the lessons only after getting permissions from the teachers of related students. Büyüköztürk, Kılıç Çakmak, Akgün, Karadeniz, \& Demirel (2012) stated that using the face-to-face interview method supplies more interaction with the respondents and this increases the control over the implementation (p.135). During the collection of data, students were asked to answer the scale most appropriately, indicating that there was no correct or incorrect answer.

\subsection{Analyzing of Data}

In the data analyses because of the modifications were done on the scale first, the reliability of the scale assessed using Cronbach's Alpha and Split-Half Reliability methods. According to analyze results Cronbach's Alpha calculated as .89 and Spearman-Brown-Coefficient value calculated as .84. Than expletory factor analyze method was used to explain the implicit structure of the scale. The suitability of the data for factor analysis examined by Kaiser-Meier-Olkin (KMO) and Barlett's test of Sphericity tests. Analyze results revealed that KMO value was .91 and Barlett's test of Sphericity X2 value was $883.98(\mathrm{p}<0.001)$. Because the KMO was higher than .60, and the Barlett test was also significant we concluded that the data were appropriate for factor analysis (Seçer, 2015, p. 79). According to expletory factor analyze (EFA) result, we determined that the scale support a one-dimensional structure that explains $57.99 \%$ of the total variance. Confirmatory factor analysis (CFA) was performed to examine the model fit of the implicit structure obtained by exploratory factor analysis. To determine the hypothesis tests to be used in the 
study, the distribution of the data examined by One-Sample Kolmogorov-Smirnov test and histograms were plotted to determine the kurtosis and skewness values. According to the analysis results, One Sample KS value calculated as $2.148(\mathrm{p}<.05)$; skewness value calculated as -.824 , and kurtosis value calculated as .043 and we determined that the data show a distorted distribution to the left. So, Mann Whitney U and Kruskal Wallis tests used as the hypothesis tests $(\alpha=.05)$.

\section{Results}

Table 1. Factor Loads of the Items and the Total Variance Explained

\begin{tabular}{cc}
\hline Item & Factor Loading \\
\hline 1 & .745 \\
2 & .841 \\
3 & .768 \\
4 & .812 \\
5 & .723 \\
6 & .759 \\
7 & .769 \\
8 & .661 \\
\hline
\end{tabular}

Description: According to analyze result the factor loadings of the items change between .661 (item 8) and .841 (item 2).

Table 2. Confirmatory Factor Analysis Fit Indicates Results

\begin{tabular}{ccccc}
\hline & Perfect Fit & Acceptable fit & Study Finding & Result \\
\hline $\boldsymbol{X}^{\mathbf{2}} \boldsymbol{p}$ & $>.05$ & - & .10 & Perfect fit \\
$\boldsymbol{X}^{\mathbf{2}} \boldsymbol{D} \boldsymbol{F}$ & $<2$ & $<5$ & 1.43 & Perfect fit \\
$\boldsymbol{R} \boldsymbol{M S E \boldsymbol { A }}$ & $<.05$ & $<.08$ & .04 & Perfect fit \\
$\boldsymbol{R} \boldsymbol{M} \boldsymbol{R}$ & $<.05$ & $<.08$ & .04 & Perfect fit \\
$\boldsymbol{S} \boldsymbol{R} \boldsymbol{M} \boldsymbol{R}$ & $<.05$ & $<.08$ & .03 & Perfect fit \\
$\boldsymbol{C F I}$ & $>.95$ & $>.90$ & 1.0 & Perfect fit \\
GFI & $>.95$ & $>.90$ & .97 & Perfect fit \\
AGFI & $>.95$ & $>.90$ & .94 & Acceptable fit \\
\hline
\end{tabular}

Source: (Çapık, 2014, Meydan \& Şeşen, 2011, p.37).

Table 3. Transformational Leadership Behavior According to Leisure Preference

\begin{tabular}{llllcc}
\hline & Leisure preferences & $\mathrm{N}$ & Mean rank & $\mathrm{H}$ & $\mathrm{P}$ \\
\hline Transformational & Home based & 74 & 90.51 & & \\
Leadership & Physical & 76 & 133.24 & 16.245 & .000 \\
behavior & Social & 76 & 116.14 & & \\
& total & 226 & & & \\
\hline
\end{tabular}

Description: According to Kruskal Wallis's test result, participants' transformational leadership behavior significantly differed according to leisure preference $(\mathrm{H}=16.245, \mathrm{SD}=2, \mathrm{p}=.000, \mathrm{p}<.01)$. A separate Mann Whitney $\mathrm{U}$ test was performed to identify in which groups the significant differences were between at an alpha level .0167 . Analyze results revealed that the significant difference was between the participants who prefer physical activities and who prefer home-based activities. 
Table 4. Transformational Leadership Behavior According to Participation Type

\begin{tabular}{ccccccc}
\hline & $\begin{array}{c}\text { Participation } \\
\text { type }\end{array}$ & $\mathrm{N}$ & $\begin{array}{c}\text { Mean } \\
\text { Rank }\end{array}$ & $\begin{array}{c}\text { Sum of } \\
\text { ranks }\end{array}$ & U & P \\
\hline Transformational & Active & 167 & 126.28 & 21088. & 2793. & .000 \\
Leadership behavior & Passive & 59 & 77.34 & 4563. & & \\
& Total & 226 & & & & \\
& & & & &
\end{tabular}

Description: According to Mann Whitney U results, participants' transformational leadership behavior significantly differs according to participation type in leisure activities $(\mathrm{p}<.01)$.

\section{Discussion}

This paper aimed to analyze transformational leadership behaviors of high school students according to leisure preference and participation type. Study results showed that students who prefer physical activities in their leisure time had a significantly higher score than students who preferred home-based or social activities (table 3 ). When we think about the positive aspects of physical activities on human behavior in the extent of leadership, this result is seen to be predictable. Also, when we examine the literature, we can see that this result supported by previous studies. For example in his study Basoglu (2013a) found a parallel result with the present finding. Also, research by Ekinci, Üstün, \& Bişğin (2016) indicated that leisure preference effects transformational leadership behavior. However, in their study, unlike our findings, Ekinci et al. (2016) found that students who chose home-based activities got the higher score than students who chose physical activities. Different results existing in the literature can be the consequence of the characteristics of the participants.

Also, the study analyzes results revealed that students who are active in participating in leisure activities had higher points than the students who are passive participators (table 4). So, we can say that high school students who actively involves in leisure activities are more able to produce new opportunities and practical solutions to potential risks than the students who choose passive participation in these activities. When we examine the literature, we can see studies with parallel or different results. For example in his study Basoglu (2013b), although found a correlation between transactional leadership behavior and leisure participation, he did not see any relationship with transformational leadership.

\section{Conclusion}

According to Karaküçük (2005, p.258), leadership constitutes one of the critical factors of leisure practices and has a function which is vital for the success and sustainability of leisure activities. For this reason, we believe that active participation in leisure activities and using their free time wisely will help high school students in developing their leadership behaviors. Because, leadership opportunities for students may be available in educational and leisure settings (Lieberman, Arndt \& Daggett, 2007). Also, the sustainability of positive outcomes of leisure activities can be possible only through the right education of young leisure leaders who respect the different needs and abilities of their friends and can lead them to the problems they face.

\section{Acknowledgments}

An earlier version of this study presented as an oral presentation in the 3rd Recreation Congress, Eskisehir.

\section{References}

Akoğlan Kozak, M. (2017). Liderlik. In Akoğlan Kozak, M. (Ed.), Rekreasyonel liderlik ve turist rehberliği (pp. 62-87). Detay Yayıncilık. $1^{\text {st }}$ press.

Andrea, L. (2011). Transformational-Transactional Leadership Theory. AHS Capstone Projects. Paper 17. Retrieved from http://digitalcommons.olin.edu/ahs_capstone_2011/17

Asakitikpi, A. O., Adeyemi, A., \& Nnamani, J. A. (2018). Socialization through Leisure: a Case Study of Nickelodeon Cable Television. International Journal of the Sociology of Leisure, 1(1), 99-115. https://doi.org/10.1007/s41978-018-0008-8

Avolio, B. J., \& Yammarino, F. J. (2013). Reflections, closing thoughts, and future directions. In B. J. Avolio \& F. J. Yammarino (Eds.), Transformational and charismatic leadership: The road ahead (pp. 449-470). Bingley: Emerald Group Publishing. https://doi.org/10.1108/S1479-357120130000005032 
Başoğlu, U. D. (2013a). Relationships between participation in recreational activities and leadership behavior: A Study on the secondary school students. Turkish Journal of Sport and Exercise, 15(2), 100-106.

Basoglu, U. D. (2013b). The relationship between the leadership behaviors and participation in the recreational activities: An empirical study on Istanbul. Journal of Tourism and Research, 2(2), 57-68.

Bass, B. (1990). Bass and Stogdill's Handbook of Leadership(3rd ed.). New York: Free Press.

Bass, B. M. (1985). Leadership and Performance beyond Expectations. New York, NY: Free Press.

Bass, B. M. (1999). Two decades of research and development in transformational leadership. European Journal of Work and Organizational Psychology, 8(1), 9-32. https://doi.org/10.1080/135943299398410

Bass, B. M., \& Avolio, B. J. (1993). Transformational leadership: A response to critiques. In M. M. Chemers \& R. Ayman (Eds.), Leadership theory and research (pp. 49-80). Toronto, Canada: Academic Press.

Bass, B. M., \& Stogdill, R. M. (1989). The handbook of leadership. New York: Free Press.

Bryman, A. (1992). Charisma and leadership in organizations. London: Sage.

Burns, J. M. (1978). Leadership. New York, NY: Harper and Row.

Büyüköztürk, Ş., Kılı̨̧ Çakmak, E., Akgün, Ö.E., Karadeniz, Ş., \& Demirel, F. (2012). Bilimsel Araştırma Yöntemleri $\left(11^{\text {th }}\right.$ ed.). Ankara: Pegem Akademi.

Çapık, C. (2014). Geçerlik ve Güvenirlik Çalışmalarında Doğrulayıcı Faktör Analizinin Kullanımı. Anadolu Hemşirelik ve Sağllk Bilimleri Dergisi, 17(3), 196-205.

Ekinci, N. E., Üstün, Ü. D., \& Bişğin, H. (2016). The effect of gender and leisure preference on transformational leadership behavior of high school students. Shs Web of Conferences, 31, 01003. http://dx.doi.org/10.1051/63100

Fields, D., \& Herold, D. (1997) Using the leadership practices inventory to measure transformational and transactional leadership. Educational \& Psychological Measurement, 57(4), 569-580. https://doi.org/10.1177/0013164497057004003

Gardner, J. W. (1990). On leadership. New York: Free Press.

Jordan, D. J. (2007). Leadership in Leisure Services: Making a Difference(3rd ed.). Venture Publishing Inc.

Kanagasabai, P. S., Mulligan, H., Hale, L. A., \& Mirfin-Veitch, B. (2018). "I do like the activities which I can do..." Leisure participation experiences of children with movement impairments. Disability and rehabilitation, 40(14), 1630-1638. https://doi.org/10.1080/09638288.2017.1303093

Karaküçük, S. (2005). Rekreasyon Boş Zamanları Değerlendirme (6th ed.). Ankara: Gazi Kitabevi.

Leithwood, K., \& Jantzi, D. (2000). The effects of transformational leadership on organizational conditions and student engagement with school. Journal of Educational Administration, 38, 112-129. https://doi.org/10.1108/09578230010320064

Lieberman, L. J., Arndt, K., \& Daggett, S. (2007). Promoting leadership in physical education and recreation. Journal of Physical Education, Recreation \& Dance, 78(3), 46-50. https://doi.org/10.1080/07303084.2007.10597989

Lowe, K. B., Kroeck, K. G., \& Sivasubramaniam, N. (1996). Effectiveness correlates of transformational and transactional leadership: A meta-analytic review of the MLQ literature. The Leadership Quarterly, 7(3), 385-415. http://dx.doi.org/10.1016/S1048-9843(96)90027-2

Meydan, C. H., \& Şeşen, H. (2011). Yapısal Eşitlik Modellemesi AMOS Uygulamalar(1st ed.). Ankara: Detay Yayincilik.

Sabuncuoğlu, E. T. (2008). Liderlik, değişim ve yenilik. In Serinkan, C. (Eds.), Liderlik ve motivasyonda geleneksel ve güncel yaklaşımlar (p. 70). Ankara: Nobel Yayın Dağıtım.

Schmiedeberg, C., \& Schröder, J. (2017). Leisure activities and life satisfaction: An analysis with German panel data. Applied Research in Quality of Life, 12(1), 137-151. https://doi.org/10.1007/s11482-016-9458-7

Seçer, İ. (2015). Psikolojik Test Geliştirme ve Uyarlama Süreci SPSS ve Lisrel Uygulamaları(1 ${ }^{\text {st }}$ ed.). Ankara: Anı Yayıncilik.

Serinkan, C. (2008). Liderlik ve motivasyonda güncel konular. In Serinkan, C. (Eds.), Liderlik ve motivasyonda 
geleneksel ve güncel yaklaşımlar (p. 151). Ankara: Nobel Yayın Dağıtım.

Sun, J., \& Leithwood, K. (2012). Transformational school leadership effects on student achievement. Leadership and Policy in Schools, 11, 418-451. http://dx.doi.org/10.1080/15700763.2012.681001

Torkildsen, G. (2005). Leisure and Recreation Management(1st ed.). Abingdon, Oxon: Routledge. https://doi.org/10.4324/9780203401651

Ural, A., \& Kılıç, İ. (2011). Bilimsel Araştırma Süreci ve SPSS İle Veri Analizi(3rd ed.). Ankara: Detay Yayıncılık. 